\title{
HNF1B wt Allele
}

National Cancer Institute

\section{Source}

National Cancer Institute. HNF1B wt Allele. NCI Thesaurus. Code C70998.

Human HNF1B wild-type allele is located within 17cen-q21.3 and is approximately $59 \mathrm{~kb}$ in length. This allele, which encodes hepatocyte nuclear factor 1-beta protein, plays a role in the modulation of transcription in hepatocytes. Mutations that add a premature stop codon to the gene are a factor in the occurrence of maturity-onset of diabetes, type 5. 